\title{
Analysis of labile form of aluminum and heavy metals in bottom sediments from Kongsfjord, Isfjord, Hornsund fjords
}

\author{
Marcin Frankowski • Anetta Zioła-Frankowska
}

Received: 28 August 2012/Accepted: 22 April 2013/Published online: 11 August 2013

(C) The Author(s) 2013. This article is published with open access at Springerlink.com

\begin{abstract}
The paper presents study results obtained for the bottom sediment samples of fjords Kongsfjord, Isfjord, Hornsund in the form of surface samples and their core profiles. The concentrations of labile form of aluminum and heavy metals were determined using the single-stage extraction with $3 \mathrm{~mol} \mathrm{~L}^{-1} \mathrm{HCl}$. The obtained results allowed defining the occurrence of variability of labile aluminum form in the samples of bottom sediments of the studied fjords depending on the point and depth of sample collection. The conducted chemometric analysis allowed for the study of spatial variability of aluminum occurrence in the area of the investigated fjords. Based on the analysis, the correlations between aluminum and heavy metals were determined.
\end{abstract}

Keywords Aluminum - Heavy metals · Bottom sediments · Fractionation · Kongsfjord · Isfjord · Hornsund · Spitsbergen

\section{Introduction}

Spitsbergen is Norway's largest island located in the Svalbard Archipelago on the Arctic Sea. Over half of the area of Spitsbergen is covered by glaciers, the rest of the island is made up of mountains and seaside lowlands. The permanent snow borderline is from $200 \mathrm{~m}$ above sea level in the south-east to $800 \mathrm{~m}$ above sea level in the north of Western Spitsbergen. Most glaciers are of the mountainous nature and flow into the sea. Most of the archipelago's area,

M. Frankowski $(\bowtie) \cdot$ A. Zioła-Frankowska

Department of Water and Soil Analysis, Adam Mickiewicz

University, Umultowska 89b, 61-614 Poznan, Poland

e-mail: marcin.frankowski@amu.edu.pl especially Western Spitsbergen, is formed of massive mountains. The mountains in the central part of Spitsbergen and those on the islands of Edge and Barents are made of flat slabs of sedimentary rocks; they have steep slopes and flat tops. Metamorphic and eruptive rocks form sharp, ragged peaks, which are typical for the north-western and south-western coast of Western Spitsbergen. The western and northern coasts of Western Spitsbergen are deeply penetrated by numerous fjords (narrow and deep sea bays) (Svedensen et al. 2002; Hop et al. 2002). Hornsund is the most southward fjord in Spitsbergen. It separates Sorkappland (the Southern Cape Land) in the east from Wedel Jarlsberg Land in the north. The length of the fjord is about $30 \mathrm{~km}$, its average depth is about $90 \mathrm{~m}$, and its maximum depth amounts to $260 \mathrm{~m}$. The fjord runs along the eastwest axis and it is perpendicular to the main regional faults of Spitsbergen. The area of the fjord and its shoreline are increasing continuously due to the diminishing glaciers. The fjord is surrounded by mountain ranges: Hornsundtind $(1,431 \mathrm{~m}$ a.s.1.) - the highest mountain in southern Spitsbergen, situated on the southern side of the fjord. The seaside lowlands are covered with abundant tundra vegetation. The Hornsund region is located in the area of South Spitsbergen National Park (Sorspitsbergen Nasjonalpark), which comprises Wedel Jarlsberg Land, Torell Land and Sorkappland along with the adjacent territorial waters (Hop et al. 2002). Due to the abundant marine fauna and flora, as well as the lack of human-caused damage, Hornsund and Kongsfjord have been included in the list of 12 European Flagship Biodiversity Sites within the Framework EU Programme (Svedensen et al. 2002). In terms of morphology and hydrology, Hornsund is clearly divided into two basins: the outer basins (with good water exchange with the area of the shelf) and the inner one (separated by moraine thresholds with restricted contact with the shelf 
water). The outer part is marked by summer temperatures higher than the temperatures in the inner part by $2-3{ }^{\circ} \mathrm{C}$. Surface salinity is higher in the outer part, while the bottom salinity is higher in the inner part, which is the effect of the deposition of post-winter, dense and very cold bottom water (Węsławski et al. 2006). Kongsfjord is one of the most famous fjords of Northern and Central Spitsbergen. It constitutes a separate natural land of Svalbard. KongsfjorKongsfjord is located in the western part of Spitsbergen. It is an open fjord, the shelf-fjord exchange significantly influences the physical and biological changes in this fjord system. Kongsfjord represents the borderline between the biogeographical zones: the Atlantic zone and the Arctic zone. The fjord is $20 \mathrm{~km}$ long and from 4 to $10 \mathrm{~km}$ wide. The terrains situated in the close vicinity of Kongsfjord have been shaped by the activity of the glaciers. Isfjord is one of the 35 known fjords of Western Spitsbergen. It has the area of $7,309 \mathrm{~km}^{2}(100 \times 25 \mathrm{~km})$ and its maximum depth amounts to $425 \mathrm{~m}$. The shores of Isfjord consist to a large extent of low mountain slopes. The average temperature of the western part of Spitsbergen amounts to $-6{ }^{\circ} \mathrm{C}$ and the average atmospheric precipitation $140-440 \mathrm{~mm}$. Based on the lithostratographic studies by Levitan et al. (2008), the surface layer of sediments collected from the fjord is made of fine-grained fractions $<0.063 \mathrm{~mm}$ (brownish silt) with the addition of sand. In the study period, the content of total organic matter of the sediments amounted to $1.8 \%$ (Levitan et al. 2008).

Aluminum belongs to four most common elements occurring in soil. It is one of the most important components of soils and, to the same extent as silicon, it makes the crystal framework of soil minerals. Due to its high reactivity (standard redox potential for $\mathrm{Al}^{3+} E^{\mathrm{o}}=$ $-1.662 \mathrm{~V}$ ), it almost exclusively occurs in soils in chemically bounded state, most often as $\mathrm{Al}^{3+}$ ion in sparingly soluble crystal lattices. Aluminum may also be present as a ligand in combination with organic substance, in form of complex bounds with fulvic and humic acids included in the soil organic substance. Moreover, aluminum can create mineral and organic complexes of different hydration levels (Gardner and Comber 2003). It should be underlined that, in complex environmental matrices such as soil solutions, inorganic and organic ligands compete with $\mathrm{OH}^{-}$ for the formation of $\mathrm{Al}$ complexes which can be labile. To the labile aluminum include the following forms: exchangeable, water-soluble, total organically bound, acid extractable/soluble, weakly organically bound $\mathrm{Al}$ and also amorphous inorganic Al (Walna et al. 2005). The uses of chemical extraction can define the aluminum fractions which can be related to a potentially mobile and reactive pool of aluminum in a sample. Considering Hlavy et al. (2004), the mobile fraction is defined as the sum of the amount dissolved in the liquid phase and an amount that can be transferred into the liquid phase. Besides, generally the ecological effects of metals (for example, their bioavailability) are related to such mobile fractions rather than the total concentration (Hlavy et al. 2004). Moreover, the concentration of bioavailable metals is important, because it is this fraction that is likely to be toxic and the cause of any impact to biota. Bioavailable metals including aluminum can be natural in origin or anthropogenic, and they normally reside in the chemically reactive or labile fraction of the sediment. Depending on the physico-chemical character of the analyzed sediment, the bioavailable fraction could be adsorbed to sediments' particles such as organic matter, $\mathrm{Fe}-\mathrm{Mn}$ oxides, carbonates or amorphous sulfides (Frankowski et al. 2010). The uses of hydrochloric acid which has the reducing properties help liberate metals from $\mathrm{Fe}$ and $\mathrm{Mn}$ oxides. It is also efficient at decomposing labile organic phases and amorphous sulfides present in sediment (Snape et al. 2004).

The aims of the study were to determine the labile forms of aluminum in fjord samples using a single-stage extraction as well as to term the degree of aluminum extraction with hydrochloric acid, to examine the variability of the concentration of the labile aluminum in fjord samples depending on the location and depth of sampling and to define the co-existence of aluminum with other elements, including heavy metals by chemometric methods.

\section{Materials and methods}

The samples were collected at the turn of July and August 2010 from three fjords (Kongsfjord, Isfjord, Hornsund) located in the island of Spitsbergen (Fig. 1).

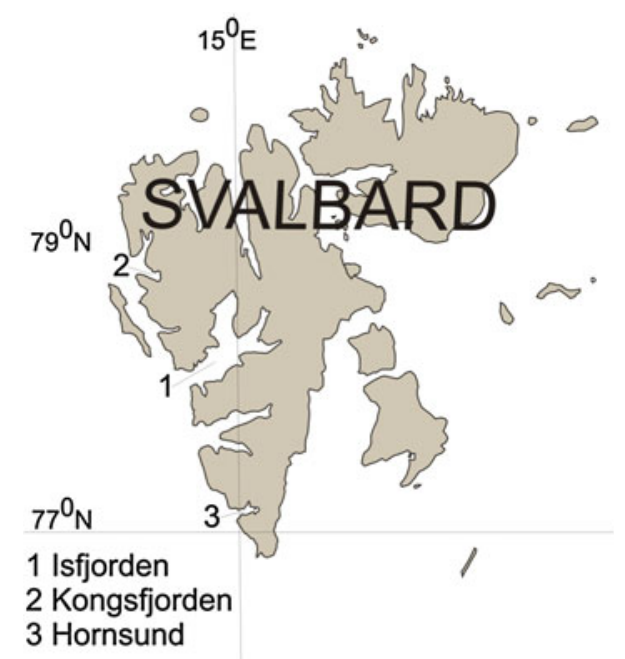

Fig. 1 Sampling points of Isfjord, Kongsfjord and Hornsund fjords 
The samples were collected using a box corer. For the purpose of the study, the samples were collected from the surface layer and, in the case of fjords Hornsund and Kongsfjord, also in the form of several-centimeter deep profiles collected every $1 \mathrm{~cm}$. The detailed description of the points of sample collection has been presented in Figs. 2, 3, 4, and the data have been listed in Table 1.

\section{Sample preparation}

After the transportation, the collected fjord samples were stored in a freezer in the temperature of $-20^{\circ} \mathrm{C}$. The samples were then freeze-dried, homogenized using an agate mortar and sieved through a $63-\mu \mathrm{m}$ sieve. The samples were then subjected to the single-stage extraction in accordance with the procedures presented in papers (Zioła-Frankowska et al. 2009; Szczuciński et al. 2007; Frankowski et al. 2009). $1.5 \mathrm{~g}$ of sediment samples was prepared and placed in $50 \mathrm{~mL}$ glass flasks. Then, $10 \mathrm{~mL}$ of $3 \mathrm{~mol} \mathrm{~L}^{-1} \mathrm{HCl}$ (Merck, Germany) acid was added to each flask. The samples were next heated in the water bath for $1 \mathrm{~h}$ in the temperature of about $95{ }^{\circ} \mathrm{C}$. To limit the evaporation of the extracting solution, a Vigreux column was placed at the cone flask's outlet. The samples were then let to cool down and filtrated into $15 \mathrm{~mL}$ polypropylene Falcon test tubes. The labile fraction of heavy metals and aluminum were determined in extracts by F-AAS analytical technique. The determination of aluminum and heavy metals was performed in 3 replications, and the \% RSD did not exceed $5 \%$. Heavy metals and aluminum were determined using the Shimadzu AA7000 spectrometer (Shimadzu, Japan).

\section{Results and discussion}

The evaluation of aluminum extraction degree based on the analysis of reference material SRM 2709

To check the analytical procedure of the determination of labile aluminum form, the determination of reference material NIST SRM 2709 (National Institute of Standards and Technology, USA) was performed. The certified value for the reference material SRM 2709 was determined by F-AAS technique. According to the producer's recommendations, mineralization was performed using the
Fig. 2 Sampling point of Isfjord fjord

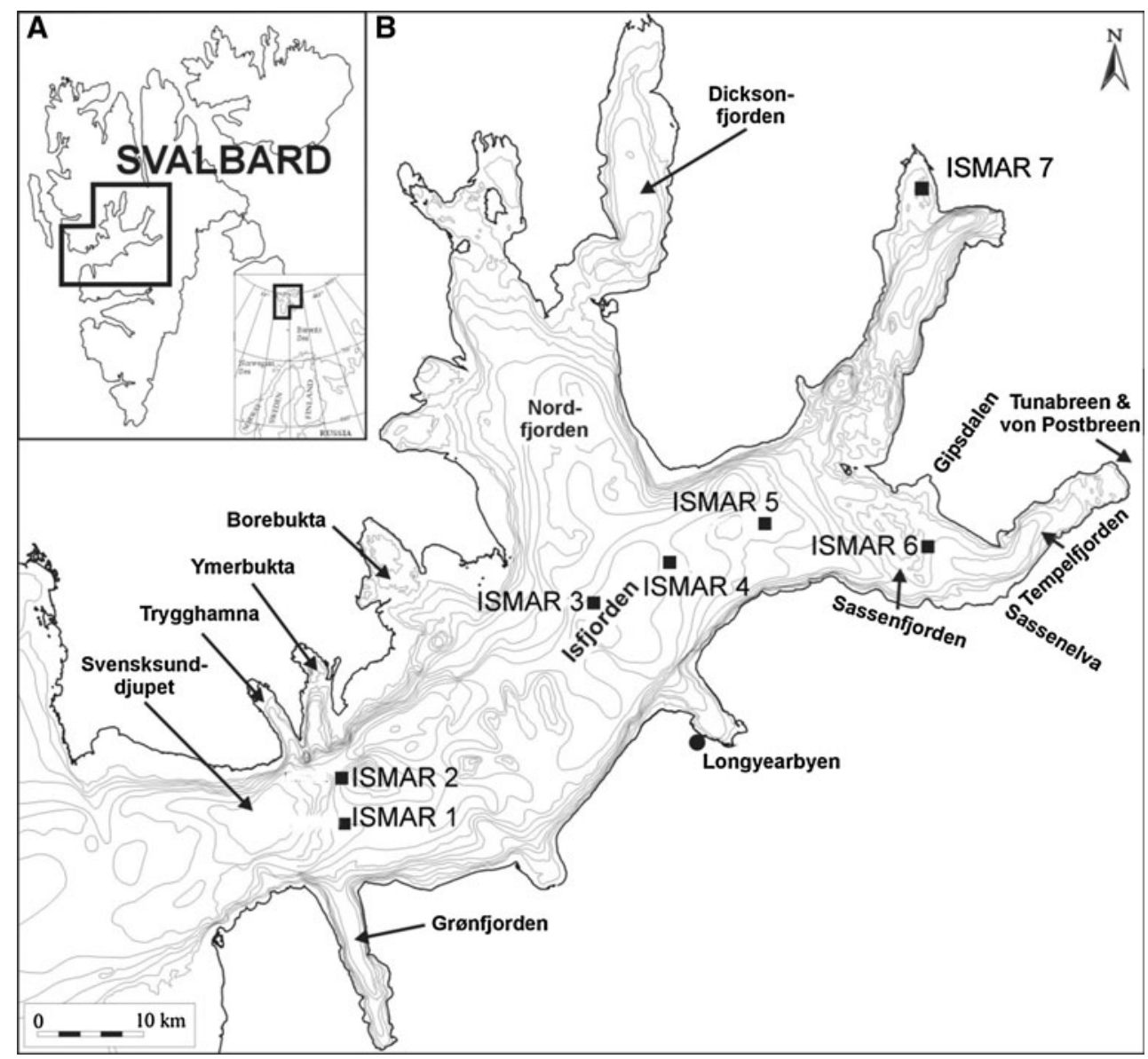


Fig. 3 Sampling points of Kongsfjord fjord
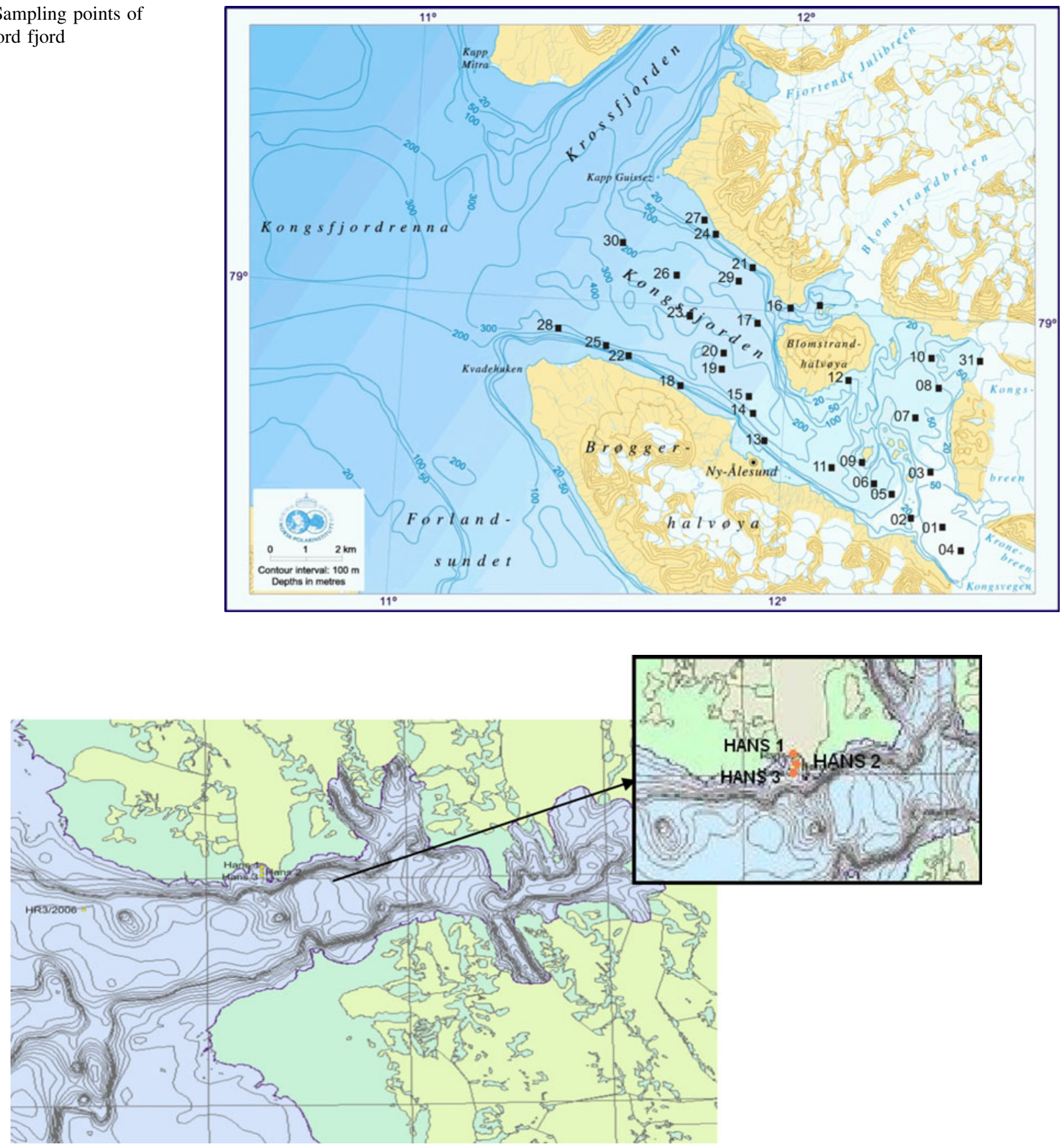

Fig. 4 Sampling points of Hornsund fjord

USEPA 3050b method recommended for SRM 2709. The reference material was analyzed during six repetitions by F-AAS technique. Moreover, [\%] of the method recovery for the extraction by PN-ISO 11466 has been presented, as well as the extraction results of the method used in the study of fjords ( $3 \mathrm{~mol} \mathrm{~L}^{-1} \mathrm{HCl}$; Merck, Germany) (ZiołaFrankowska et al. 2009; Szczuciński et al. 2007; Frankowski et al. 2009). The calculated values of basic parameters of the described analytical methods are presented in Table 2.
Results of the determinations of labile aluminum form extracted with $3 \mathrm{~mol} \mathrm{~L}^{-1} \mathrm{HCl}$ for the samples from fjords Isfjord, Kongsfjord and Hornsund

\section{Isfjord}

The samples of bottom sediments of ISFJORD were collected from seven points differentiated in terms of the place of sample collection and depth $(55-254 \mathrm{~m})$. The highest concentration of labile aluminum form was determined for 
Table 1 Sampling points of Kongsfjord, Isfjord and Hornsund fjords

\begin{tabular}{llll}
\hline Station name & Sampling depth $(\mathrm{m})$ & \multicolumn{2}{l}{ Coordinates } \\
\cline { 3 - 3 } & & $\mathrm{N}$ & $\mathrm{E}$ \\
\hline
\end{tabular}

Kongsfjord fjords

\begin{tabular}{|c|c|c|c|}
\hline KON 1 & 85 & 78.53550 & 12.23590 \\
\hline $\operatorname{KON} 2^{a}$ & 45 & 78.54019 & 12.20178 \\
\hline KON 3 & 44 & 78.55434 & 12.21258 \\
\hline KON 4 & 75 & 78.53660 & 12.28238 \\
\hline KON 5 & 75 & 78.54660 & 12.16756 \\
\hline KON 6 & 80 & 78.55015 & 12.13720 \\
\hline KON 7 & 62 & 78.56869 & 12.17698 \\
\hline KON 8 & 74 & 78.57717 & 12.20051 \\
\hline KON 9 & 27 & 78.55592 & 12.11341 \\
\hline KON 10 & 68 & 78.58559 & 12.18058 \\
\hline $\mathrm{KON} 11^{\mathrm{b}}$ & 146 & 78.55592 & 12.71770 \\
\hline KON 12 & 40 & 78.57237 & 12.67040 \\
\hline KON 13 & 145 & 78.56190 & 11.56551 \\
\hline $\mathrm{KON} 15^{\mathrm{c}}$ & 327 & 78.57758 & 11.52070 \\
\hline KON 16 & 68 & 79.00180 & 12.01200 \\
\hline KON 17 & 100 & 78.59961 & 11.55807 \\
\hline KON 18 & 250 & 78.57912 & 11.43382 \\
\hline KON 19 & 242 & 78.58497 & 11.47780 \\
\hline KON 20 & 240 & 78.59510 & 11.51788 \\
\hline KON 22 & 290 & 78.58411 & 11.38581 \\
\hline KON 23 & 285 & 78.59690 & 11.41770 \\
\hline KON 24 & 145 & 79.19910 & 11.44927 \\
\hline KON 26 & 242 & 79.08570 & 11.38550 \\
\hline KON 27 & 117 & 79.23930 & 11.40827 \\
\hline KON 28 & 258 & 78.58807 & 11.30808 \\
\hline KON 30 & 214 & 79.19470 & 11.33061 \\
\hline KON 31 & 49 & 78.58504 & 12.25143 \\
\hline
\end{tabular}

Isfjord fjords

\begin{tabular}{lrll} 
ISMAR 1 & 171 & 78.1133 & 14.10155 \\
ISMAR 2 & 171 & 78.16678 & 14.10155 \\
ISMAR 3 & 254 & 78.20479 & 15.19812 \\
ISMAR 4 & 220 & 78.25469 & 15.49137 \\
ISMAR 5 & 160 & 78.33489 & 16.23247 \\
ISMAR 6 & 200 & 78.33489 & 16.42307 \\
ISMAR 7 & 55 & 78.41329 & 16.33637 \\
Hornsund fjords & & & \\
Hans 1 & 58 & 77.0403 & 15.3757 \\
Hans 2 & 24 & 77.0242 & 15.3818 \\
Hans 3 & 25 & 77.0270 & 15.3885 \\
\hline
\end{tabular}

${ }^{\mathrm{a}}$ Core length $15 \mathrm{~cm},{ }^{\mathrm{b}}$ core length $11 \mathrm{~cm},{ }^{\mathrm{c}}$ core length $13 \mathrm{~cm},{ }^{\mathrm{d}}$ core length $11 \mathrm{~cm},{ }^{\mathrm{e}}$ core length $18 \mathrm{~cm},{ }^{\mathrm{f}}$ core length $12 \mathrm{~cm}$; slices of core cut off at $1 \mathrm{~cm}$

sample ISMAR $6\left(9,992 \mathrm{mg} \mathrm{kg}^{-1}\right)$ collected at the depth of $200 \mathrm{~m}$, while the lowest concentration was found for sample ISMAR $5\left(5,797 \mathrm{mg} \mathrm{kg}^{-1}\right)$ collected at $160 \mathrm{~m}$. Samples ISMAR 6 and ISMAR 7, for which the highest aluminum concentrations were determined, are located in the closest vicinity to the land. Therefore, it may be assumed that higher concentrations of aluminum in this part of the fjord can be caused by the migration of elements to water as a result of the natural processes of weathering of the rocks surrounded by Isfjord. Samples ISMAR 1 and ISMAR 2 were located close to each other and were collected from the same depth $171 \mathrm{~m}$. For these samples, the comparable concentrations of labile aluminum forms were determined, similar to samples ISMAR 3, ISMAR 4 and ISMAR 5, located in the central part of this fjord. Levitan et al. (2008), in the sedimentary studies of fjord Isfjord, determined the aluminum content using the X-ray fluorescence (XRF) technique and obtained the values at the level of $92 \mathrm{~g} \mathrm{~kg}^{-1}$ for the total content of aluminum in a sample (layer up to $25 \mathrm{~cm}$ ). It must be explained that the $\mathrm{XRF}$ analysis allows for the total determination of $\% \mathrm{Al}_{2} \mathrm{O}_{3}$ content in a sample. Based on Table 2, the recovery of $3 \mathrm{~mol} \mathrm{~L}^{-1} \mathrm{HCl}$ procedure caused extraction about $25.3 \pm 0.9 \%$ of pseudo-total content of aluminum extracted by EPA method 3050. The determined concentration of labile aluminum form under this study maximally amounted to about $10 \mathrm{~g} \mathrm{~kg}^{-1}$ which is estimated about $39.5 \mathrm{~g} \mathrm{~kg}^{-1}$ of pseudo-total aluminum.

Moreover, fjord samples are characterized by high \% participation of fine-grained fractions, that is $<0.063 \mathrm{~mm}$. Levitan et al. (2008) obtained the values ranging from 80 to $93 \%$ (maximum value for the depth of $7-33 \mathrm{~cm}$ ) of this fraction's participation in the whole sediment mass. Such high participation of fraction $<0.063 \mathrm{~mm}$ may be preferential for the studies of sediment chemistry as the high participation of this fraction is evidence of the high concentration in the whole sediment mass. The influence of granulation on the concentration of aluminum or heavy metals has been the subject of many studies (Frankowski et al. 2005; Kowalski et al. 2007; Frankowski et al. 2008; Sutherland 2003; Sutherland and Tack 2007). Even a minor participation of fine-grained fraction, where the highest concentrations of elements are observed, causes the increase in the participation in the whole sediment mass. Higher concentrations of aluminum or heavy metals in finegrained fractions are connected with the large specific area of these fractions, which in consequence enlarges the sorption area on the grain surface. The effect of high participation of fine-grained fractions in fjord sediments is that the results obtained for these fractions may even constitute up to $80-93 \%$ participation (based on the granulometric analysis by Levitan et al. 2008) in the whole sediment mass.

\section{Hornsund}

In the case of fjord Hornsund, the samples were collected as core profile samples from three points. The concentrations 
Table 2 The calculated values of basic parameters of the described analytical methods

\begin{tabular}{|c|c|c|c|c|c|c|c|}
\hline & $\mathrm{Cu}\left(\mathrm{mg} \mathrm{kg}^{-1}\right)$ & $\mathrm{Cr}\left(\mathrm{mg} \mathrm{kg}^{-1}\right)$ & $\mathrm{Pb}\left(\mathrm{mg} \mathrm{kg}^{-1}\right)$ & $\mathrm{Ni}\left(\mathrm{mg} \mathrm{kg}^{-1}\right)$ & $\mathrm{Zn}\left(\mathrm{mg} \mathrm{kg}^{-1}\right)$ & $\mathrm{Cd}\left(\mathrm{mg} \mathrm{kg}^{-1}\right)$ & $\mathrm{Al}\left(\mathrm{g} \mathrm{kg}^{-1}\right)$ \\
\hline Certified value & $34.6 \pm 0.7$ & $130 \pm 4$ & $18.9 \pm 0.5$ & $88.0 \pm 5.0$ & $106 \pm 3$ & $0.38 \pm 0.01$ & $75.0 \pm 0.6$ \\
\hline Determined value $^{a}$ & $33.5 \pm 0.6$ & $71.2 \pm 0.7$ & $19.6 \pm 0.5$ & $70.4 \pm 1.8$ & $85.8 \pm 1.4$ & $0.45 \pm 0.01$ & $74.9 \pm 3.4$ \\
\hline Determined value $^{\mathrm{b}}$ & $24.0 \pm 2.0$ & $38.1 \pm 1.6$ & $11.5 \pm 0.8$ & $55.3 \pm 2.3$ & $74.8 \pm 2.0$ & $0.39 \pm 0.01$ & $19.0 \pm 0.7$ \\
\hline Determined value ${ }^{c}$ & $\begin{array}{l}- \\
(\%)\end{array}$ & - & - & - & - & - & $62.5 \pm 0.4$ \\
\hline Recovery $^{\mathrm{a}}$ & $97.8 \pm 1.9$ & $54.8 \pm 1.0$ & $103.9 \pm 2.7$ & $81.4 \pm 2.4$ & $80.9 \pm 1.6$ & $118 \pm 0.9$ & $99.9 \pm 4.5$ \\
\hline Recovery $^{\mathrm{b}}$ & $69.4 \pm 5.8$ & $29.3 \pm 1.2$ & $60.8 \pm 4.2$ & $62.8 \pm 2.6$ & $70.5 \pm 3.5$ & $102.5 \pm 2.5$ & $25.3 \pm 0.9$ \\
\hline Recovery $^{\mathrm{c}}$ & - & - & - & - & - & - & $83.3 \pm 0.6$ \\
\hline
\end{tabular}

${ }^{\text {a }}$ EPA method, ${ }^{\mathrm{b}} 3 \mathrm{~mol} \mathrm{~L}{ }^{-1} \mathrm{HCl}$ method, ${ }^{\mathrm{c}}$ PN-EN-ISO 11466 method

of labile aluminum form, determined in the samples of Hans 1, Hans 2, Hans 3 core profiles, depending on the profile length are shown in Fig. 5.

For sample Hans 1, the highest concentration of labile aluminum form was determined for the sample collected at the $8-9 \mathrm{~cm}$ of the core profile length $\left(9,214 \mathrm{mg} \mathrm{kg}^{-1}\right)$, while the lowest concentration was found for the sample collected at $10-11 \mathrm{~cm}$ of the core profile length $\left(7,045 \mathrm{mg} \mathrm{kg}^{-1}\right)$. For sample Hans 2, the highest concentration of the labile form of aluminum was determined for the sample collected at $9-10 \mathrm{~cm}$ of the core profile length $\left(10,070 \mathrm{mg} \mathrm{kg}^{-1}\right)$, while the lowest concentration was found for the sample collected at $1-2 \mathrm{~cm}$ of the core profile length $\left(6,816 \mathrm{mg} \mathrm{kg}^{-1}\right)$. For sample Hans 3 , the highest concentration of the labile form of aluminum was determined for the sample collected at $9-10 \mathrm{~cm}$ of the core profile length $\left(10,980 \mathrm{mg} \mathrm{kg}^{-1}\right)$, while the lowest concentration was found for the sample collected at 10-11 cm of the core profile length $\left(6,424 \mathrm{mg} \mathrm{kg}^{-1}\right)$. When analyzing the concentration results obtained for labile aluminum

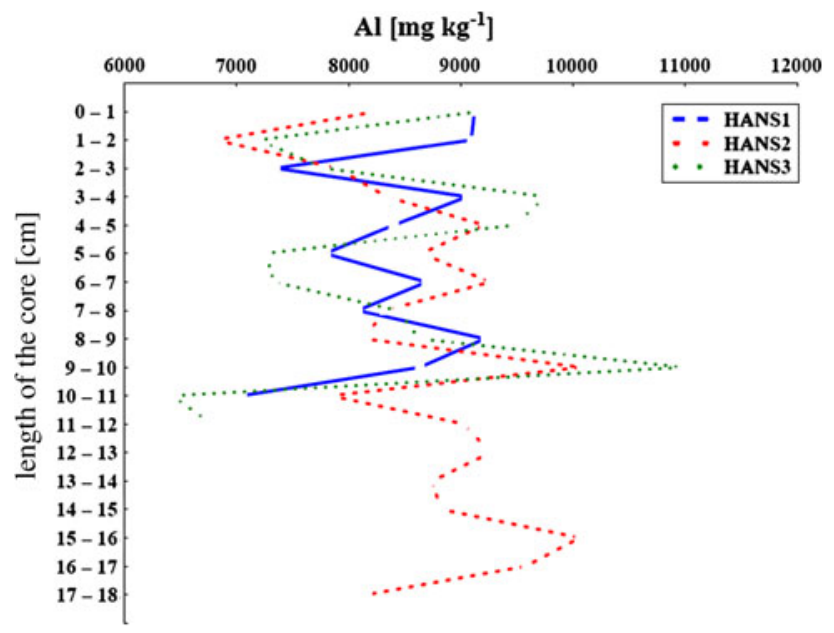

Fig. 5 Concentration of labile aluminum form for Hans 1, Hans 2 and Hans 3 sampling points in the function depending on the length of the core form along with the core profile length of the samples collected from fjord Hornsund, it can be stated that the concentration variability of labile aluminum form occurs, and that this relation is common for all the core profiles. Considering the fact that the samples from this fjord were collected at small distances from one another, from the land into the sea: Hans 1-2-3 from the depths 54-24-25 (m), no significant differences were stated in the results obtained for the $0-1 \mathrm{~cm}$ core profile sample. The variability common for all the analyzed core profiles of the fjord is most probably the result of the processes of sedimentation and migration of aluminum along the profile, which can be observed in Fig. 5. The highest aluminum concentrations occurred between 9 and $10 \mathrm{~cm}$ of the profile, and then a rapid decrease in aluminum concentration took place. Similarly, at the profile heights of 3-5 cm, the aluminum concentration increased, and at $5-6 \mathrm{~cm}$, a rapid decrease in aluminum concentration was observed.

\section{Kongsfjord}

The samples of fjord Kongsfjord were collected from the surface layer from 27 places at the depths of $27-327 \mathrm{~m}$. The 15,11 and $13 \mathrm{~cm}$ long core profiles were collected at three points for $\mathrm{KON} 2, \mathrm{KON} 11$ and $\mathrm{KON} 15$. The highest concentrations of labile aluminum form for fjord Kongsfjord were determined for sample KON 31 (12,340 $\mathrm{mg} \mathrm{kg}^{-1}$ ) collected at the depth of $49 \mathrm{~m}$. The high concentrations of labile aluminum form were also determined for samples: $\mathrm{KON} 10, \mathrm{KON} 8, \mathrm{KON} 24\left(>10,000 \mathrm{mg} \mathrm{kg}^{-1}\right)$. In the case of the group of samples from fjord Kongsfjord, the attempt to evaluate the variability concerns the place of sample collection and the inflow from land into the water-bottom sediment system, as well as the depth of fjord samples collection from the surface layer. To determine the abovementioned factors, the maps of the depth of sample collection (Fig. 6a) and the aluminum concentrations at these points (Fig. 6b) were made. 
A
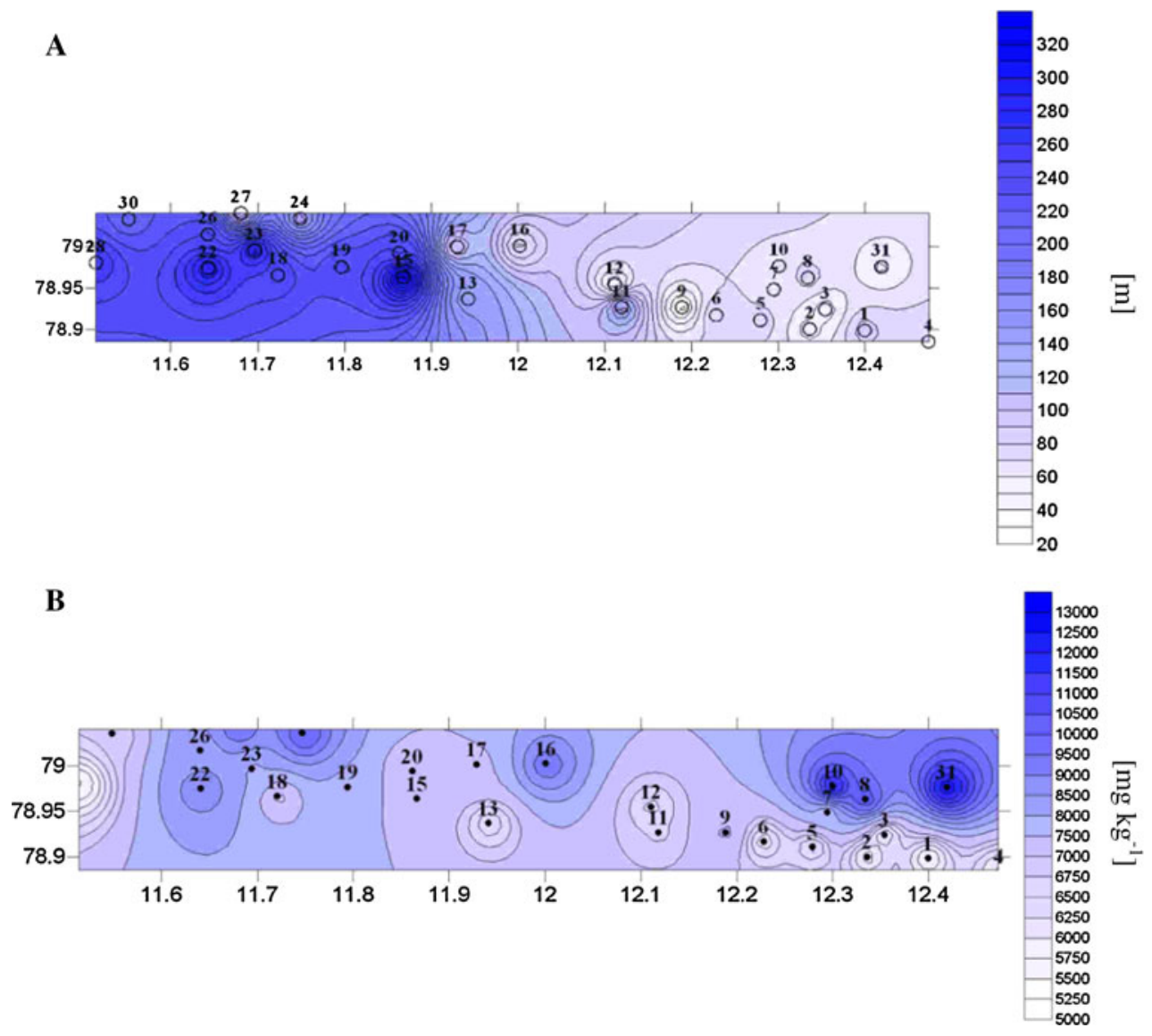

Fig. 6 a The variability of the sampling depth (m) in Kongsfjord fjord and $\mathbf{b}$ the variability of the concentration of labile form of aluminum $\left(\mathrm{mg} \mathrm{kg}^{-1}\right)$ in samples of the Kongsfjord depending on the location of sampling

Based on Fig. 6a and b, it can be stated that the highest concentrations of labile aluminum form determined in samples KON 31, KON 10 occur in the north-eastern part of the fjord, marked by the largest depths. A similar conclusion can be drawn for samples KON 24 and KON 27. In the northern part of the fjord, the concentration of labile aluminum form was higher (KON 8, KON 10, KON 16, KON 24, KON 27, KON 31) than in the south-eastern and southern belt (KON 1, KON 2, KON 3, KON 4, KON 5, KON 6, KON 11, KON 12, KON 13, KON 28). It can be related to the occurrence of natural aluminum sources in the form of sedimentary, metamorphic and eruption rocks in this area.

\section{Kongsfjord core profiles KON 2, KON 11, KON 15}

Three profile samples were collected in the area of fjord Kongsfjord. The variability of the concentration of aluminum in core profile is presented in Fig. 7.

The highest concentration of labile aluminum form in core profile KON 2 was determined for the sample collected at the depth of 5-6 $\mathrm{cm}$ of the profile length $\left(6,545 \mathrm{mg} \mathrm{kg}^{-1}\right)$, while the lowest concentration was found for the sample collected at $11-12 \mathrm{~cm}$ of the profile length $\left(4,747 \mathrm{mg} \mathrm{kg}^{-1}\right)$. For the core profile collected from point KON $11(11 \mathrm{~cm}$ profile), the highest concentration of labile aluminum form was determined for the sample collected at the depth of $5-6 \mathrm{~cm}$ of the profile length $\left(7,430 \mathrm{mg} \mathrm{kg}^{-1}\right)$, while the lowest concentration was found for the sample collected at $0-1 \mathrm{~cm}$ of the profile length $\left(5,704 \mathrm{mg} \mathrm{kg}^{-1}\right)$. In the case of sample KON 15 (profile length $13 \mathrm{~cm}$ ), the highest concentration of labile aluminum form was determined for the sample collected at the depth of $1-2 \mathrm{~cm}$ of the profile length $\left(8,657 \mathrm{mg} \mathrm{kg}^{-1}\right)$, while the lowest concentration was found for the sample collected at $12-13 \mathrm{~cm}$ of the profile length $\left(5,204 \mathrm{mg} \mathrm{kg}^{-1}\right)$. Based on the variability evaluation, it may be confirmed that aluminum concentration is higher in the northern belt in comparison with the southern one. Moreover, this trend remained for a longer time, which confirms the natural processes of elements migration to bottom sediments. The observed trend of the distribution of labile aluminum form may be linked to the process of sedimentation 


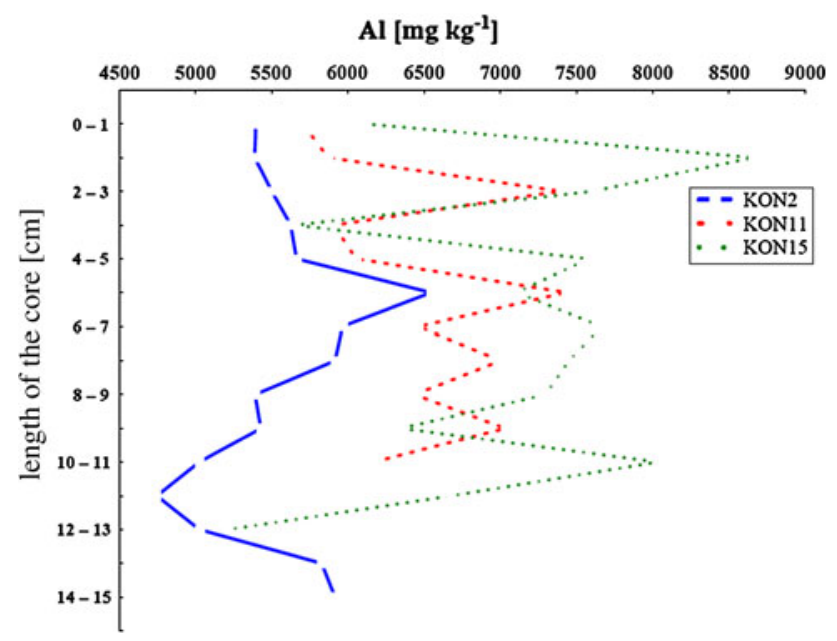

Fig. 7 The variability of the concentration of labile form of aluminum in the core profile collected from the points of $\mathrm{KON} 2$, KON 11 and KON 15

of suspended solids and other natural processes described in the case of fjords Isfjord and Hornsund.

Total content of aluminum in fjords samples

The results of total content of aluminum after mineralization with hydrofluoric acid are presented in Table 3. The percentage of labile aluminum form was calculated as the ratio of the concentration of labile $\mathrm{Al}$ form to total content of aluminum in the fjords samples. The percentage obtained for labile Al form was similar for samples of Kongsfjord (around $30 \%$ ); for Isfjord, the percentage was divided into two groups: around $16 \%$ and around $35 \%$. For core samples of Hansfjord and Kongsfjord, the content of aluminum was higher for Hansfjords cores that that for Kongsfjord cores. We compare the percentage of the labile fraction of aluminum values and found it was higher for Kongsfjord than for Hansfjord.
Heavy metals and aluminum

The conducted single-stage extraction with $3 \mathrm{~mol} \mathrm{~L}^{-1} \mathrm{HCl}$ allowed determining labile form of aluminum and heavy metals in fjords samples from Spitsbergen. The results obtained for heavy metals and Al have been presented in the table as min-max values for particular surface samples of the fjords (Isfjord, Kongsfjord) and as min-max values for the profiles of fjords Kongsfjord and Hornsund (Table 4).

It is worth emphasizing that investigations conducted for the area of Spitsbergen have been the subject of many studies, but mostly the data concerning microbiology and sedimentology can be found (Walkusz et al. 2004; Elverhøi et al. 1980; Elverhøi et al. 1983; Zajączkowski and Legeżyńska 2001; Szczuciński et al. 2009). While the chemical analysis of determination of total and pseudo total concentrations of aluminium and heavy metals form Spitsbergen fjords was rarely conducted.

Gulińska et al. (2003) determined the pseudo-total content of $\mathrm{Al}\left(34.56-277.25 \mathrm{mg} \mathrm{kg}^{-1}\right), \mathrm{Pb}\left(0.14-9.33 \mathrm{mg} \mathrm{kg}^{-1}\right), \mathrm{Zn}$ $\left(0.49-12.77 \mathrm{mg} \mathrm{kg}^{-1}\right)$, Fe $\left(29.38-389.8 \mathrm{mg} \mathrm{kg}^{-1}\right)$, Mn (2.12-78.07 $\mathrm{mg} \mathrm{kg}^{-1}$ ) in soil samples collected from the central part of Spitsbergen using the procedure with $\mathrm{HNO}_{3}$ (V) and $\mathrm{H}_{2} \mathrm{O}_{2}(30 \%)$. However, in comparison with the results obtained for fjord samples (Table 3, this work), the pseudo-total concentration of $\mathrm{Al}$ and $\mathrm{Pb}, \mathrm{Zn}, \mathrm{Fe}$ and $\mathrm{Mn}$ in soil samples of the central Spitsbergen is characterized by significantly lower content, despite the fact that in the case of research by Gulińska et al. (2003) a much stronger extractants were used. It may be stated that the concentrations of the presented elements in soils are characterized by the geochemical background, and the soils in this area are subject to continuous processes of weathering and migration, e.g. to the water depth, from where they can be sedimented to the bottom sediments of the analyzed fjords.

Table 3 The results obtained for heavy metals and Al (min-max values) for particular surface samples of the fjords (Isfjord, Kongsfjord) and as min-max values for the profiles of fjords Kongsfjord and Hornsund

\begin{tabular}{|c|c|c|c|c|c|c|c|c|c|}
\hline $\begin{array}{l}\text { Sampling } \\
\text { location/area }\end{array}$ & $\begin{array}{l}\mathrm{Cd} \\
\left(\mathrm{mg} \mathrm{kg}^{-1}\right)\end{array}$ & $\begin{array}{l}\mathrm{Cr} \\
\left(\mathrm{mg} \mathrm{kg}^{-1}\right)\end{array}$ & $\begin{array}{l}\mathrm{Cu} \\
\left(\mathrm{mg} \mathrm{kg}^{-1}\right)\end{array}$ & $\begin{array}{l}\mathrm{Ni} \\
\left(\mathrm{mg} \mathrm{kg}^{-1}\right)\end{array}$ & $\begin{array}{l}\mathrm{Pb} \\
\left(\mathrm{mg} \mathrm{kg}^{-1}\right)\end{array}$ & $\begin{array}{l}\mathrm{Zn} \\
\left(\mathrm{mg} \mathrm{kg}^{-1}\right)\end{array}$ & $\begin{array}{l}\mathrm{Mn} \\
\left(\mathrm{mg} \mathrm{kg}^{-1}\right)\end{array}$ & $\begin{array}{l}\mathrm{Al} \\
\left(\mathrm{g} \mathrm{kg}^{-1}\right)\end{array}$ & $\mathrm{Fe}\left(\mathrm{g} \mathrm{kg}^{-1}\right)$ \\
\hline \multicolumn{10}{|l|}{ Fjord/core } \\
\hline Isfjord $^{\mathrm{a}}$ & $0.30-0.95$ & $17.1-46.6$ & $13.3-18.7$ & $23.0-34.7$ & $8.0-24.2$ & $40.6-54.4$ & $185-666$ & $6.00-10.0$ & $14.95-32.16$ \\
\hline Kongsfjord $^{\mathrm{b}}$ & $0.52-0.97$ & $12.5-23.0$ & $9.8-20.3$ & $12.9-20.4$ & $7.4-36.8$ & $30.3-136$ & $174-359$ & $5.46-12.3$ & $9.90-23.7$ \\
\hline Hans $1^{\mathrm{c}}$ & $0.39-0.53$ & $11.7-15.4$ & $9.9-13.0$ & $19.9-26.2$ & $11.8-23.5$ & $32.7-43.3$ & 149-188 & $7.05-9.21$ & $12.94-19.13$ \\
\hline Hans $2^{\mathrm{c}}$ & $0.37-0.49$ & $12.7-16.9$ & $9.9-14.7$ & $21.2-28.9$ & $9.3-50.3$ & $32.7-43.8$ & 139-190 & $6.82-10.07$ & $11.68-22.61$ \\
\hline Hans $3^{\mathrm{c}}$ & $0.39-0.49$ & $10.5-15.6$ & $7.4-12.1$ & $19.4-27.6$ & $7.5-28.0$ & $31.6-44.1$ & $141-174$ & $6.42-11.0$ & $13.40-17.53$ \\
\hline $\mathrm{KON} 2^{\mathrm{c}}$ & $0.82-0.99$ & $11.0-14.0$ & $7.9-11.2$ & $12.2-15.1$ & $3.1-23.6$ & $25.1-33.0$ & $219-256$ & $4.75-6.55$ & $9.45-17.62$ \\
\hline $\mathrm{KON} 11^{\mathrm{c}}$ & $0.76-0.92$ & $12.1-14.3$ & $7.5-12.7$ & $13.0-15.9$ & $6.0-18.7$ & $28.4-39.7$ & 198-309 & $5.71-7.43$ & $98.0-14.18$ \\
\hline $\mathrm{KON} 15^{\mathrm{c}}$ & $0.68-0.94$ & $12.2-17.8$ & $6.8-11.6$ & $14.6-17.9$ & $11.0-22.7$ & $27.8-44.1$ & $154-342$ & $5.20-8.66$ & $3.18-18.65$ \\
\hline
\end{tabular}

${ }^{\mathrm{a}}$ ISMAR $1-7,{ }^{\mathrm{b}} \mathrm{KON}$ surface, ${ }^{\mathrm{c}}$ core 
Table 4 The total content of aluminum and the $\%$ of labile aluminum form in fjords samples

\begin{tabular}{|c|c|c|}
\hline Core & $\begin{array}{l}\text { Total content } \mathrm{Al} \\
(\min -\max ) \text { in } \mathrm{g} \mathrm{kg}^{-1}\end{array}$ & $\begin{array}{l}\% \text { of labile } \mathrm{Al} \\
(\min -\max )\end{array}$ \\
\hline Hans $1 *$ & $32.4-51.3$ & $15.19-27.38$ \\
\hline Hans $2 *$ & $44.7-68.4$ & $10.97-20.74$ \\
\hline Hans $3 *$ & $46.1-68.8$ & $12.08-17.46$ \\
\hline KON 2* & $17.1-26.7$ & $22.18-38.18$ \\
\hline KON $11 *$ & $19.9-27.8$ & $21.76-35.31$ \\
\hline KON $15^{*}$ & $25.3-31.5$ & $19.62-28.35$ \\
\hline Sample & Total content of $\mathrm{Al}$ in $\mathrm{g} \mathrm{kg}^{-1}$ & $\%$ of labile $\mathrm{Al}$ \\
\hline ISMAR 1 & 43.1 & 16.57 \\
\hline ISMAR 2 & 45.1 & 15.71 \\
\hline ISMAR 3 & 42.6 & 15.59 \\
\hline ISMAR 4 & 44.9 & 16.15 \\
\hline ISMAR 5 & 16.3 & 35.64 \\
\hline ISMAR 6 & 29.1 & 34.34 \\
\hline ISMAR 7 & 33.6 & 25.37 \\
\hline KON 1 & 19.3 & 29.58 \\
\hline KON 2 & 18.9 & 30.84 \\
\hline KON 3 & 21.5 & 27.71 \\
\hline KON 4 & 18.9 & 31.56 \\
\hline KON 5 & 20.8 & 29.57 \\
\hline KON 6 & 18.2 & 33.24 \\
\hline KON 7 & 26.5 & 28.89 \\
\hline KON 8 & 29.9 & 35.05 \\
\hline KON 9 & 19.9 & 38.06 \\
\hline KON 10 & 34.8 & 34.23 \\
\hline KON 11 & 24.2 & 27.76 \\
\hline KON 12 & 18.4 & 35.01 \\
\hline KON 13 & 19.5 & 32.48 \\
\hline KON 15 & 26.2 & 27.05 \\
\hline KON 16 & 24.8 & 37.65 \\
\hline KON 17 & 24.8 & 29.95 \\
\hline KON 18 & 15.6 & 44.18 \\
\hline KON 19 & 24.6 & 32.23 \\
\hline KON 20 & 26.8 & 26.25 \\
\hline KON 22 & 24.8 & 35.87 \\
\hline KON 23 & 32.9 & 24.18 \\
\hline KON 24 & 26.1 & 38.51 \\
\hline KON 26 & 28.2 & 29.47 \\
\hline KON 27 & 22.9 & 41.12 \\
\hline KON 28 & 42.9 & 12.74 \\
\hline KON 30 & 27.3 & 24.73 \\
\hline KON 31 & 42.9 & 28.77 \\
\hline
\end{tabular}

Heavy metals $(\mathrm{Cd}, \mathrm{Cu}$ and $\mathrm{Pb})$ in sediment from $\mathrm{Ad}-$ ventfjord and Grønfjord located in the Isfjord system, Svalbard, after microwave digestion with a combination of $\mathrm{HF}$ and aqua regia were determined by Holte et al. (1996).
The concentrations of heavy metals in the surface sediments of the Adventfjord and Grønfjord were 0.08-0.12 $\mathrm{mg} \mathrm{kg}^{-1}$ for $\mathrm{Cd}, 27.1-30.8 \mathrm{mg} \mathrm{kg}^{-1}$ for $\mathrm{Cu}$ and $19.5-26.0 \mathrm{mg} \mathrm{kg}^{-1}$ for $\mathrm{Pb}$. In comparison, the concentration of heavy metals in fjords samples from Isfjord (this work) after extraction with $3 \mathrm{M} \mathrm{HCl}$ was $0.302-0.954 \mathrm{mg} \mathrm{kg}^{-1}$ for $\mathrm{Cd}, 13.3-18.7 \mathrm{mg} \mathrm{kg}^{-1}$ for $\mathrm{Cu}$ and $8.0-24.2 \mathrm{mg} \mathrm{kg}^{-1}$ for $\mathrm{Pb}$. It is worth noting that the determined concentrations for samples Ismar, especially for $\mathrm{Cu}$ and $\mathrm{Pb}$, are comparable with the results of the total content of these metals in sediments marked by Holte et al. (1996), despite the use of a much weaker extractant. It can be stated that metals are occluded on the surface of the grain (Frankowski et al. 2008).

Regarding the determination of the labile form of heavy metals in fjords sample from Spitsebergen area, there is a lack in the literature. Melke (2006) determined the form available to plants by extracting the soils of the Bellsund (Spitsbergen) with DTPA-TEA (diethylenetriaminepenta acetic acid) extractant. The contents of DTPA-TEA extractable $\mathrm{Cu}, \mathrm{Zn}, \mathrm{Pb}, \mathrm{Cd}$ and $\mathrm{Mn}$ were as follows: $0.17-24.76, \quad 0.18-45.28, \quad 0.10-25.30, \quad 0.02-1.30$, and $0.56-371.09 \mathrm{mg} \mathrm{kg}^{-1}$, respectively. The concentrations of available metals by Melke (2006) are lower as against the concentrations of labile form of heavy metals in fjords samples. It was observed that in both analyzed type of samples, the high concentration of manganese was determined.

The extraction procedure by the dilute $\mathrm{HCl}$, similar to this work, was applied by Snape et al. (2004) for the purpose of assessing the labile metal contaminants in Antarctic marine sediments. Snape et al. (2004) extracted sediments by $1 \mathrm{M} \mathrm{HCl}$ at different times $(0.5$ and $4 \mathrm{~h})$. The determined concentration of labile form of heavy metals after $0.5 \mathrm{~h}$ time extraction was $0.02-0.11 \mathrm{mg} \mathrm{kg}^{-1}$ for $\mathrm{Cd}$, $0.04-2.1 \mathrm{mg} \mathrm{kg}^{-1}$ for $\mathrm{Cr}, 0.2-14 \mathrm{mg} \mathrm{kg}^{-1}$ for $\mathrm{Cu}, 0.2-2$ $\mathrm{mg} \mathrm{kg}^{-1}$ for Ni, $0.1-45 \mathrm{mg} \mathrm{kg}^{-1}$ for $\mathrm{Pb}, 2.5-40 \mathrm{mg} \mathrm{kg}^{-1}$ for $\mathrm{Zn}, 2-4 \mathrm{mg} \mathrm{kg}^{-1}$ for $\mathrm{Mn}$ and $100-2,500 \mathrm{mg} \mathrm{kg}^{-1}$ for Fe. Comparing these results to the concentrations marked for the same metals in the fjords samples (Table 3, this work), it can be concluded that they are present at a similar level concentrations, particularly in the case of $\mathrm{Pb}, \mathrm{Zn}$ and $\mathrm{Cu}$.

Chemometric evaluation of the variability of aluminum occurrence in fjord samples Spatial variability:

coexistence of aluminum and other elements

The analysis of principal components of the studied fjord samples was performed for the whole set of data comprising both surface samples and core profile samples collected for fjords Hornsund and Kongsfjord. The analysis of principal components was performed on a data set which was subjected to normalization following the transformations 


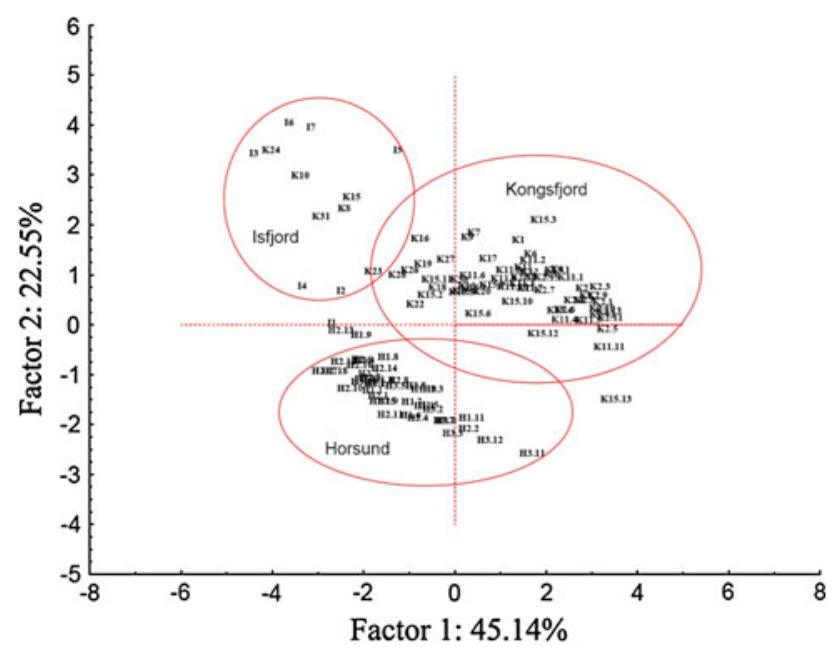

Fig. 8 Principal component analysis for samples of Isfjord, Hornsund, Kongsfjord fjords (determined elements $\mathrm{Al}, \mathrm{Cd}, \mathrm{Cr}, \mathrm{Cu}, \mathrm{Ni}, \mathrm{Pb}$, $\mathrm{Zn}, \mathrm{Fe}, \mathrm{Mn})$

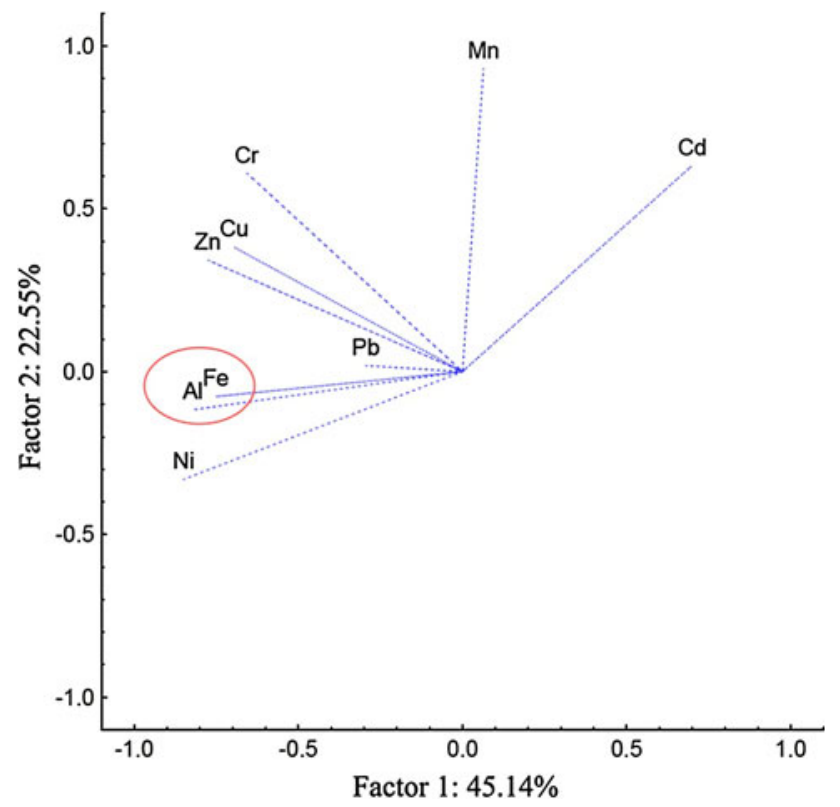

Fig. 9 Principal component analysis for the analyzed elements :Al, $\mathrm{Cd}, \mathrm{Cr}, \mathrm{Cu}, \mathrm{Ni}, \mathrm{Pb}, \mathrm{Zn}, \mathrm{Fe}, \mathrm{Mn}$

necessary for meeting the conditions of chemometric analysis. The transformations described by Mazerski (2004) were used. The variance for the first four components in the analyzed data set was, respectively, 45.14, 22.55, 11.06 and $6.40(\%)$ (summary value $85.20 \%$ ). The chemometric analysis of samples is presented in Fig. 8.

Based on the PCA, three groups of samples were distinguished, characteristic for particular studied fjords, both in terms of samples collected from the surface layer of bottom sediments and for the core profiles collected from particular fjords. It should be underlined that the area of Spitsbergen is not exposed to pollution due to human industrial activity.
The main processes of bottom sediment formation include the sedimentation of suspended solids which get to water as a result of a number of physico-chemical processes. Moreover, the PCA indicated the division of particular fjords into differentiated systems, which at the same time are marked by certain individual characteristics. For the same data matrix, the analysis of principal components was performed for the studied elements (Fig. 9).

The chemometric analysis confirms the relationship between the occurrence of aluminum and iron, due to the similarity of these two elements and to the occurrence level of both iron and aluminum. In the surface water systems, $\mathrm{Fe}$ coexists mainly with $\mathrm{Mn}$. The analysis of factor loads indirectly indicates the correlations between these elements. Factor loads (without rotation) presented in Table 5 confirm the strong correlation between $\mathrm{Fe}$ and $\mathrm{Al}$, as well as between $\mathrm{Cd}, \mathrm{Ni}$ and $\mathrm{Zn}$ (factor 1) and $\mathrm{Mn}$ (factor 2).

On the other hand, the factor loads distinguished with the normalized varimax rotation indicate strong correlation between $\mathrm{Cd}, \mathrm{Mn}, \mathrm{Ni}$ (factor 1) and $\mathrm{Cr}, \mathrm{Cu}, \mathrm{Zn}$ (factor 2).

The varimax rotation allows for the easier interpretation of results as the varimax looks for such a set of factor loads

Table 5 Factor loadings (without rotation) for the analyzed data matrix

\begin{tabular}{lcc}
\hline Element & Factor 1 & Factor 2 \\
\hline $\mathrm{Al}$ & $-0.821328^{\mathrm{a}}$ & -0.116935 \\
$\mathrm{Fe}$ & $-0.752133^{\mathrm{a}}$ & -0.076591 \\
$\mathrm{Mn}$ & 0.064252 & $0.930239^{*}$ \\
$\mathrm{Cd}$ & $0.700442^{\mathrm{a}}$ & 0.632554 \\
$\mathrm{Cr}$ & -0.656974 & 0.609368 \\
$\mathrm{Cu}$ & -0.696110 & 0.382009 \\
$\mathrm{Ni}$ & $-0.849627^{\mathrm{a}}$ & -0.330752 \\
$\mathrm{~Pb}$ & -0.294632 & 0.018517 \\
$\mathrm{Zn}$ & $-0.776337^{\mathrm{a}}$ & 0.342361 \\
\hline
\end{tabular}

${ }^{a}$ Marked loads are $>0.7$

Table 6 Factor loadings (with varimax rotation) for the analyzed data matrix

\begin{tabular}{lrr}
\hline Element & Factor 1 & Factor 2 \\
\hline $\mathrm{Al}$ & 0.646910 & 0.519385 \\
$\mathrm{Fe}$ & 0.570159 & 0.496477 \\
$\mathrm{Mn}$ & $-0.722745^{\mathrm{a}}$ & 0.589163 \\
$\mathrm{Cd}$ & $-0.940513^{\mathrm{a}}$ & -0.078619 \\
$\mathrm{Cr}$ & 0.004536 & $0.896060^{\mathrm{a}}$ \\
$\mathrm{Cu}$ & 0.197204 & $0.769162^{\mathrm{a}}$ \\
$\mathrm{Ni}$ & $0.822286^{\mathrm{a}}$ & 0.393839 \\
$\mathrm{~Pb}$ & 0.187941 & 0.227660 \\
$\mathrm{Zn}$ & 0.280991 & $0.800596^{\mathrm{a}}$ \\
\hline
\end{tabular}

${ }^{a}$ Marked loads are $>0.7$ 
at which each factor has certain loads near 0 and certain loads near $-1,+1$. The interpretation of results is much easier when the correlations between the variable and the factor reach the values near $-1,+1$ (there is no correlation at the value near 0) (Table 6).

The results of factor loads and $\mathrm{Al}$ and $\mathrm{Fe}$ correlations could be expected, but the analysis with varimax rotation indicates $\mathrm{Mn}, \mathrm{Cd}$ and $\mathrm{Ni}$ correlation. In such studies, the analysis of the results is difficult, mainly due to complicated processes of exchange and migration of elements between systems. Melke (2006) in the study of soils in Bellsund (Spitsbergen) observed a strong correlation between $\mathrm{Cd}$ and $\mathrm{Mn}$ for heavy metal fractions which define the concentration of elements as toxic for plants.

\section{Conclusions}

A single-stage extraction with $3 \mathrm{~mol} \mathrm{~L}{ }^{-1} \mathrm{HCl}$ allowed for the distinguishing of aluminum labile form in fjord samples (Isfjord, Kongsfjord, Hornsund). The studies of fjords revealed that aluminum concentration in particular fjords varies and depends on the local conditions and processes taking place in the system of a given fjord. The highest concentrations of labile aluminum form were determined in the samples located at the smallest distance from land for fjord Isfjord. On the other hand, for fjord Kongsfjord, the highest concentrations of the labile form of aluminum were determined in the samples from the north-eastern belt area. This belt was marked by high concentrations of the determined aluminum form in comparison with lower concentrations of this aluminum form in the central and southern belts. For the samples of fjord core profiles (KON 2, KON 11, KON 15), the decrease in labile aluminum form was stated along with the increasing length of the studied profiles. The lack of variability in the concentration of labile aluminum form along with the profile lengths from fjord Hornsund was found (Hans 1, Hans 2, Hans 3). Based on the analysis of fjord Isfjord and macroscopic analysis, it was revealed that high concentrations of aluminum, heavy metals may be caused by the high participation of fraction $<0.063 \mathrm{~mm}$. The chemometric analysis confirmed the relationship between the occurrence of aluminum and iron. Moreover, based on the PCA, a correlation between $\mathrm{Cd}$ and $\mathrm{Mn}$ concentrations was observed in the investigated samples of bottom sediments.

\footnotetext{
Acknowledgments The authors wish to thank Dr. Witold Szczucinski from Adam Mickiewicz Univeristy for fjords samples and valuable comments to the paper.
}

Open Access This article is distributed under the terms of the Creative Commons Attribution License which permits any use, distribution, and reproduction in any medium, provided the original author(s) and the source are credited.

\section{References}

Elverhøi A, Liestøl O, Nagy J (1980) Glacial erosion, sedimentation and microfauna in the inner part of Kongsfjorden, Spitsbergen. Nor Polarinst Skr 172:33-62

Elverhøi A, Lønne O, Seland R (1983) Glaciomarine sedimentation in a modern fjord environment, Spitsbergen. Polar Res 1(2):127-149

Frankowski M, Sobczyński T, Zioła A (2005) The effect of grain size structure on the content of heavy metals in alluvial sediments of the Odra river. Polish J Environ Stud 14:81-86

Frankowski M, Zioła A, Siepak M, Siepak J (2008) Analysis of heavy metals in particular granulometric fractions of bottom sediments in the Mała Wełna River (Poland). Pol J Environ Stud 17:343-350

Frankowski M, Siepak M, Zioła A, Novotny K, Vaculovič T, Siepak J (2009) Vertical distribution of heavy metals in grain size fractions in sedimentary rocks: Mosina-Krajkowo water well field, Poland. Environ Monit Asses 155(1-4):493-507

Frankowski M, Zioła-Frankowska A, Kowalski A, Siepak J (2010) Fractionation of heavy metals in bottom sediments using Tessier procedure. Environ Earth Sci 60:1165-1178

Gardner MJ, Comber SDW (2003) Aluminium speciation in effluents and receiving waters. J Environ Monit 5:902-905

Gulińska J, Rachlewicz G, Szczuciński W, Barałkiewicz D, Kózka M, Bulska E, Burzyk M (2003) Soil contamination in the high Arctic areas of human impact, Central Spitsbergen, Svalbard. Pol J Environ Stud 12(6):701-707

Hlavy J, Prohaska T, Weisz M, Wenzel WW, Stingeder GI (2004) Determination of trace elements bound to soils and sediment fractions. Pure Appl Chem 76:415-442

Holte B, Dahle S, Gulliksen B, Naes K (1996) Some macrofaunal effects of local pollution and glacier-induced sedimentation, with indicative chemical analysis, in the sediments of two Artic fjords. Polar Biol 16:549-557

Hop H, Pearson T, Hegseth EN, Kovacs KM, Wiencke C, Kwasniewski S, Eiane K, Mehlum F, Gulliksen B, WlodarskaKowalczuk M, Lydersen C, Weslawski JM, Cochrane S, Gabrielsen GW, Leakey R, Lønne OJ, Zajaczkowski M, FalkPetersen S, Kendall M, Wangberg SA, Bischof K, Voronkov A, Kovaltchouk NA, Wiktor J, Poltermann M, di Prisco G, Papucci C, Gerland S (2002) The marine ecosystem of Kongsfjorden, Svalbard. Polar Res 21:167-208

Kowalski A, Siepak M, Frankowski M, Zioła A (2007) Determination of mercury in sedimentary rock samples using cold vapour atomic fluorescence spectrometry. Oceanol Hydrobiol Stud 36:143-153

Levitan MA, Levchenko OV, Murdmaa IO, Peresypkin VI, Roshichina IA, Tolmacheva AV (2008) History of sedimentation in Isfjord (Western Spitsbergen) Lithol. Miner Res 43:520-541

Mazerski J (2004) Fundamentals of chemometrics. Gdańsk Univeristy of Technology, Gdansk

Melke J (2006) Heavy metals in soils and vascular plants of the bellsund area. (Spitsbergen). Pol J Soil Sci 39:21-32

PN-ISO 11466 (2002) Soil quality. Extraction of trace elements soluble in aqua regia

Snape I, Scouller RC, Stark SC, Stark J, Riddle MJ, Gore DB (2004) Characterization of the dilute $\mathrm{HCl}$ extraction method for the identification of the metals contamination in Artic marine sediments. Chemosphere 57:491-504

Sutherland RA (2003) Lead in grain size fractions of road-deposited sediment. Environ Pollut 121:229-237

Sutherland RA, Tack FMG (2007) Sequential extraction of lead from grain size fractionated river sediments using the optimized BCR procedure. Water Air Soil Pollut 184:269-284 
Svendsen H, Beszczynska-Møller A, Hagen JO, Lefauconnier B, Tverberg V, Gerland S, Ørbæk JB, Bischof K, Papucci C, Zajaczkowski M, Azzolini R, Bruland O, Wiencke C, Winthe JG, Dallmann W (2002) The physical environment of Kongsfjorden-Krossfjorden, an Arctic fjord system. Polar Res 21:133-166

Szczuciński W, Niedzielski P, Kozak L, Frankowski M, Zioła A, Lorenc S (2007) Effect of rainy season on mobilization of contaminants from tsunami deposit left in a coastal zone of Thailand by the 26.12.2004 tsunami. Environ Geol 53:253-264

Szczuciński W, Zajączkowski M, Sholten J (2009) Sediment accumulation rates in subpolar fjords-impact of post-Little Ice Age glaciers retreat, Billefjorden, Svalbard. Estuar Coast Shelf Sci 85:345-356

USEPA. Method 3050b. Acid digestion of sediments, sludges and soils

Walkusz W, Kwaśniewski S, Dmoch K, Hop H, Żmijewska MI, Bielecka L, Falk- Petersen S, Siciński J (2004) Characteristics of
Arctic and Antarctic mesozooplankton in the neritic zone during summer Pol. Polar Res 25:275-291

Walna B, Spychalski W, Siepak J (2005) Assesment of potentially reactive pools of aluminium in poor forest soil using two methods of fractionation analysis. J Inorg Biochem 99:1807-1816

Węsławski JM, Kwaśniewski S, Stempniewicz L, BłachowiakSamołyk K (2006) Biodiversity and energy transfer to top trophic levels in two contrasting Arctic fiords. Pol Polar Res 27:259-278

Zajączkowski MJ, Legeżyńska J (2001) Estimation of zooplankton mortality caused by an Arctic glacier outflow. Oceanologia 43:341-351

Zioła-Frankowska A, Frankowski M, Szczuciński W, Siepak J (2009) Analysis of labile aluminium form in grain size fractions of tsunami deposits in Thailand. Pol J Environ Stud 18:77-85 